\title{
Gammaspectrometry and mineralogy of carbonate sediments of Brejo do Espinho Lake (RJ) during the Holocene
}

\author{
Luiz Gustavo Rodrigues de Sá Valle1, Catia Fernandes Barbosa², Carla Semiramis da Silveira², Camila Areias de Oliveira², \\ Nayara Dornelas ${ }^{3}$, Daniel François do Nascimento Silva ${ }^{3}$, José Carlos Sícoli Seoane 4 \\ 1- Department of Geology and Geophysics - Universidade Federal Fluminense Niterói, Rio de Janeiro, CEP 24.210-346, Brazil. \\ 2- Department of Geochemistry - Universidade Federal Fluminense, Outeiro São João Batista, s/n, Centro, Niterói, Rio de Janeiro CEP 24.020-141, Brazil. \\ 3- Department of Marine Biology - Universidade Federal Fluminense, Outeiro de São João Batista, s/no., CEP 24020-141, Brazil \\ 4- Department of Geology - Universidade Federal do Rio de Janeiro, Rio de Janeiro, CEP 21.941-916, Brazil.
}

Copyright 2019, SBGf - Sociedade Brasileira de Geofísica

This paper was prepared for presentation during the $16^{\text {th }}$ International Congress of the Brazilian Geophysical Society held in Rio de Janeiro, Brazil, 19-22 August 2019.

Contents of this paper were reviewed by the Technical Committee of the $16^{\text {th }}$ International Congress of the Brazilian Geophysical Society and do not necessarily represent any position of the SBGf, its officers or members. Electronic reproduction or storage of any part of this paper for commercial purposes without the written consent of the Brazilian Geophysical Society is prohibited.

\section{Abstract}

The Brejo do Espinho Lake is, located in Costa do Sol Park in the state of Rio de Janeiro - Brazil, is one of the few places in the world where dolomite currently precipitates. The site is characterized by the deposition of calcareous sediments with high magnesium content and the presence of a semi-arid microclimate due to the upwelling zone around the Cabo Frio region. Previous studies have shown that the microbial activity supports the formation of sinsedimentary dolomite and significantly influences the isotopic composition of the sulfur and the concentration of sulfate dissolved in the water of the lake. These characteristics and modern dolomites are considered rare in the world, and important, since it is a mineral widely found in the geological record, especially in Precambrian carbonate rocks, commonly associated to microbial structures, and also as important rock analogues of oil reservoirs and in paleolimnological studies.

This study is part of a project of the Department of Geochemistry of Universidade Federal Fluminense (UFF) in partnership with ETH-Zürich and Université de Genève, Switzerland, with the specific objective of evaluating the sedimentary evolution of Brejo do Espinho Lake through stratigraphy and physico-chemical properties of the sediments during the Holocene. The methodology of the characterization of the stratigraphy, geochemistry, physical properties, and mineralogy applied to the sedimentary succession is effective as a tool in the reconstruction of paleoenvironmental evolution.

\section{Introduction}

In the coastal region of the state of Rio de Janeiro, between the cities of Guaratiba and Cabo Frio, sedimentary plains occur, with two lagoonal sequences separated by sandy barriers of different ages (Martin et al., 1997; Turcq et al., 1999; Villwock et al., 2005). The internal sand bar sequence is formed by large and rounded lagoons, such as Araruama, Jacarepaguá, and
Rodrigo de Freitas, of Pleistocene ages. Smaller, thinly elongated lagoons and lakes, such as the Marapendi, Vermelha, Brejo do Espinho and Pernambuca (Turcq et al., 1999), form the outer sequence, with Holocene age.

The Brejo do Espinho lake (Figure 1), is located approximately $100 \mathrm{~km}$ east of the Rio de Janeiro city, near the Praia Seca village (Saquarema municipality), between coordinates $22^{\circ} 55^{\prime} 47.6^{\prime \prime} \mathrm{S}, 42^{\circ} 20^{\prime} 58.52^{\prime \prime} \mathrm{W}$, with an area of $1 \mathrm{~km}^{2}$ and a water column that varies between $2 \mathrm{~cm}$ and 1.5m (Anjos et al., 2003). Furthermore, according to Vasconcelos \& Mackenzie (1997), the lake is also controlled by climatic variations, where during rainy seasons, the input of meteoric water increases, raising the level of the water, while during in the dry season, the lake is controlled mainly by water percolation of the Araruama lagoon and the Atlantic Ocean.

The environment is characterized by the presence of microbial mats and precipitation of primary dolomite. Dolomite is a mineral widely found in the geological record, especially in pre-Cambrian carbonate rocks, commonly associated with microbial structures. However, their scarcity in modern environments and inability to be synthesized at low temperatures in laboratory, hamper the understanding of the environmental variables associated with their formation and diagenesis. One of the fundamental factors for the occurrence of microbialites associated with dolomite is the microclimate of the Cabo Frio region due to the semi-arid characteristics imposed by the oceanographic upwelling of cold and nutrient rich South Atlantic Central Water (SACW), favoring a high evaporation on the coastal hypersaline environments (Valentin, 1984).

In the 80 's, when the formation of primary dolomite was discovered in the hypersaline environment of the neighbor Vermelha lake (Hohn et al., 1986; Vasconcelos, 1988), it was observed that microorganisms, specially the sulfate reducing bacteria, had a fundamental role in the formation of dolomite precipitation (Van Lith et al., 2002). Vasconcelos \& McKenzie (1997) proposed a model for the formation of dolomite through microbiological action, in association with geochemical and climatic factors, advancing the studies of dolomite's precipitation problem.

The microbialites, carbonate rocks formed by microbial action and their environment of formation have been relevant for understanding the evolutionary history of the Earth and related paleoenvironments. Microbialites are currently found in the hypersaline lagoons in the state of 
Rio de Janeiro, and may be associated with the microbial origin of the carbonates that can constitute the pre-salt reservoirs, which include dolomitic carbonate rocks.

This study investigates the sedimentary paleoenvironment of Brejo do Espinho Lake through stratigraphy and geochemistry, based on total count gamma-spectrometric analysis, also carried of the most common radioactive elements: Potassium (K), Uranium $(\mathrm{U})$, and Thorium (Th), and others physical properties such as grain size, mineralogy, magnetic susceptibility and $p$-wave velocity. We expect to understand the paleolimnological evolution of this environment, which represents a modern analogue of one of the largest oil discoveries int Brazil, the pre-salt.
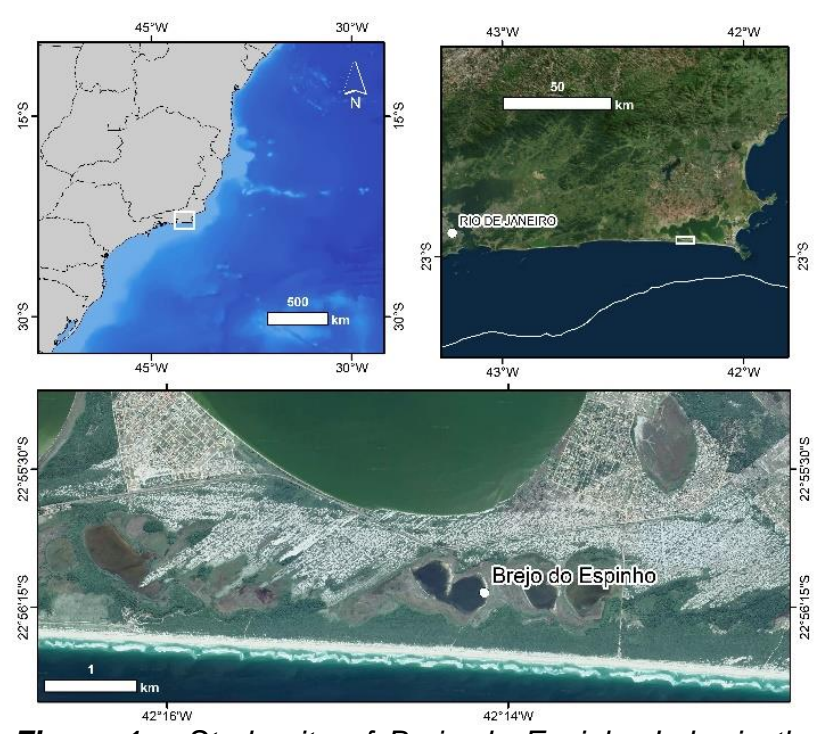

Figure 1 - Study site of Brejo do Espinho Lake in the southeast Brazil on the east coast of Rio de Janeiro state.

\section{Method}

The sedimentary core was obtained in June 2018 using PVC tube manually pushed into the sediment as deep as possible and then withdrawn. The core was identified as LBE18-1 and has a length of $100 \mathrm{~cm}$.

To analyze the physical properties, the core was examined with a Multi-Sensor Core Logger (MSCL) manufactured by GEOTEK, in the Physical Geography Laboratory (LAGEF) at the Department of Geology and Geophysics of the Universidade Federal Fluminense (UFF). The sampling resolution for these analyses was $0.5 \mathrm{~cm}$ with $250 \mathrm{kHz}$, in order to obtain the p-wave velocity, gamma-density and porosity.

In the laboratory of sedimentology of the Geochemistry Department (UFF) the core was cut longitudinally in two halves, described in detail and photographed. One half was stored as an archive, the other was used for the physical, and sedimentary analyzes. After that, the gamma spectrometric analysis was made using the model RS-230-BGO by Radiation Solution with measurements in intervals of $2.5 \mathrm{~cm}$. This analysis allowed us to detect the total radiation emitted, as well as that emitted by
Potassium (K), Uranium (U), and Thorium (Th), in order to identify clay contents of different geological units using chemical stratigraphy and the relation between the influence of marine and continental sedimentation.

The core was sliced into $2 \mathrm{~cm}$ thick segments, identified, closed in zip lock bags and stored in a freezer at $+4 \stackrel{\circ}{\circ}$, and then slplit into aliquots for additional analysis.

For the grain size analysis, each $2 \mathrm{~g}$ aliquot was decarbonated using $\mathrm{HCl}(1 \mathrm{~N})$ and placed on a vibrating platform until the end of the reaction, washed with distilled water and centrifuged to remove excess acid. After this, the organic matter was removed with hydrogen peroxide $\left(\mathrm{H}_{2} \mathrm{O}_{2}\right)$ and, after the end of the reaction, the sample was washed again. Sodium hydroxide (40\%) was added to disaggregate the particles present in the sample. The grain-size measurements were performed using a laser particle analyzer (CILAS ${ }^{\circledR}$ 1064), which has a detection range of $0.02-2000 \mu \mathrm{m}$, using the grain size statistics method of Folk and Ward (1957) performed in GRADISTAT software version 8.0 (Blott and Pye, 2001) to interpret the results.

Other $2 \mathrm{~g}$ aliquots were used for mineralogical analysis after the removal of the organic matter with hydrogen peroxide $\left(\mathrm{H}_{2} \mathrm{O}_{2}\right)$ and homogenization through maceration. In the X-ray diffraction laboratory at UFF, the aliquots were placed on the sample tray and the material smoothed to avoid the presence of surface imperfections, as these would interfere in the acquisition of the diffraction data, changing diffraction peaks, and generating unsatisfactory responses with a high probability of significant errors (Langford, 1996). X-ray diffractograms were obtained in the BRUKER D8 ADVANCE equipment, with LYNXEYE detector using Bragg-Brentano geometry, under the following conditions: angular range $(2 \theta)$ between $5^{\circ}$ and $100^{\circ}$, angular pitch of $0.02^{\circ}$ and time of collection by $0.8 \mathrm{~s}$ step. The measurements of the interplanar distances and the relative intensities of the peaks in the diffractogram were obtained by the program PowderCell 2.4 (PCW), where the interplanar spacing was compared with the values presented in the book "Crystal structures of clay minerals and the x-ray identification" by Brindley \& Brown (1980) to identify minerals in the aliquots.

\section{Results}

The LBE 18-1 core presented grain size alternation, with the predominance of sand in the samples closest to the top, while at greater depths silt predominates. The percentages varied from $0 \%$ to $99.45 \%$ (mean of $49.87 \%$ and standard deviation of $41.95 \%$ ) for the sand content, from $0.13 \%$ to $97.25 \%$ (mean of $46.11 \%$ and standard deviation of $39.14 \%$ ) for the silt content and from $0.20 \%$ to $14.06 \%$ (mean of $4.02 \%$ and standard deviation of $3.96 \%$ ) for clay (Figure 2).

The grain size ranged from $5.69 \mu \mathrm{m}$ to $205.61 \mu \mathrm{m}$ (mean of $97.60 \mu \mathrm{m}$ and standard deviation of $87.71 \mu \mathrm{m}$ ).Several characteristics of marine sediments, such as density, porosity, interstitial fluid and confinement pressure, are factors that interfere with the $p$-wave velocity (AYRES- 
NETO, 1998). The Vp profile obtained from LBE18-1 showed variations between $1376.15 \mathrm{~m} / \mathrm{s}$ and $1673.53 \mathrm{~m}$ / s (average of $1605.9 \mathrm{~m} / \mathrm{s}$ and standard deviation of
$33.14 \mathrm{~m} / \mathrm{s}$ ). At $25 \mathrm{~cm}$ and $55.5 \mathrm{~cm}$ depths, a decrease in grain

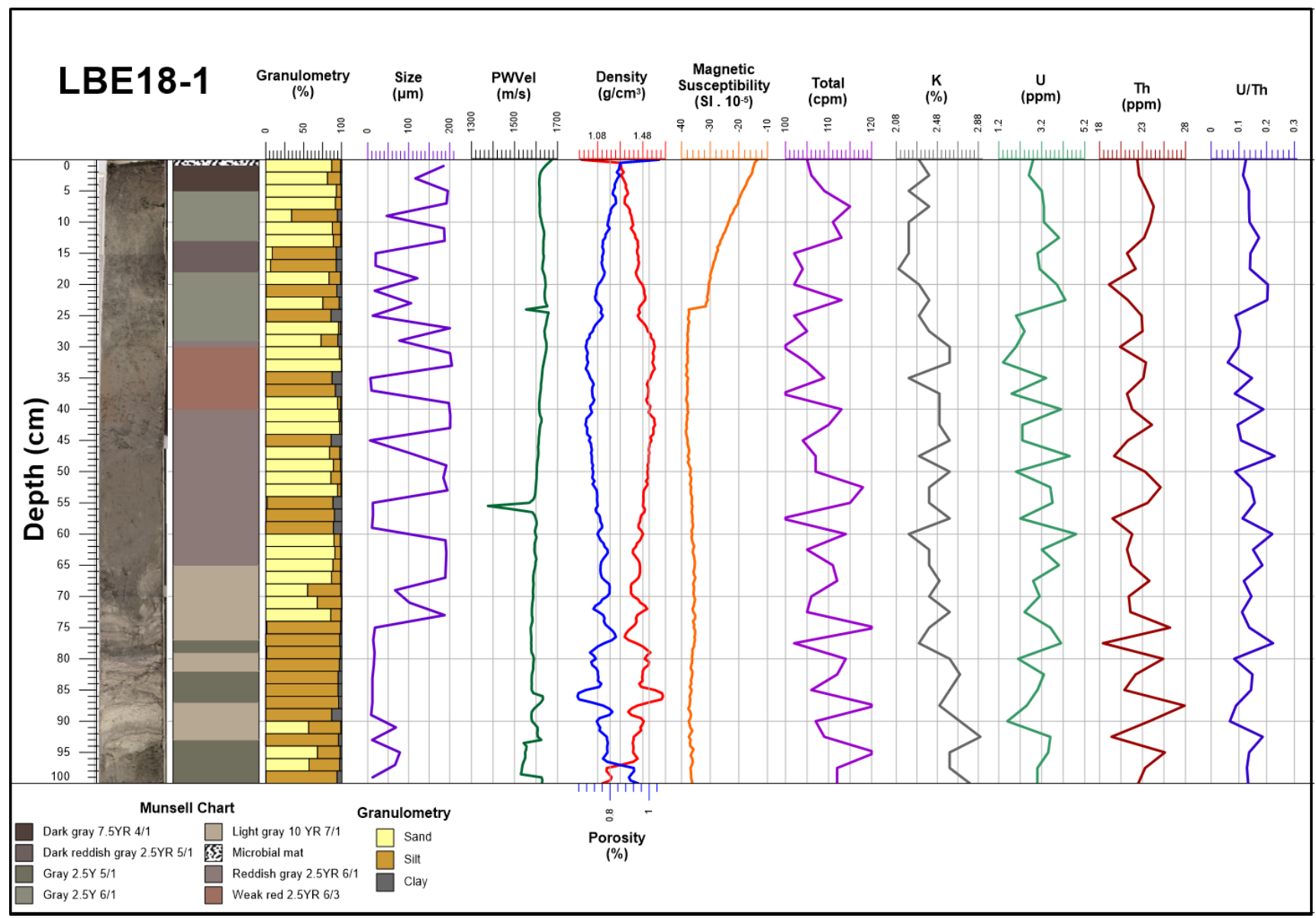

Figure 2 - Representation of particle size analysis in percentage and $\mu \mathrm{m}$, seismic profiling and gamma spectrometry of the core LBE18-1 at Brejo do Espinho Lake.

size was observed $(12.17 \mu \mathrm{m}$ and $12.44 \mu \mathrm{m}$ respectively) along the highest percentages of clay $(14.06 \%$ and $11.66 \%$, respectively) corroborating the inferred $\mathrm{Vp}$ decrease.

In addition, close to the base of the core, between $85 \mathrm{~cm}$ and $95 \mathrm{~cm}$, a predominance of sandy sediments with large amounts of silt and clay was observed, in which the finer sediment filled the pores between coarse grains, decreasing porosity. These results corroborate those found by Hamilton (1979); Kim et al. (2001), Macedo (2006), who verified that the higher velocities are related to sediments of greater grain size.

Porosity is defined as the volume of the empty space between the grains occupied by the water, in gas-free sediments (HAMILTON, 1976) and has a relation inversely proportional to grain size. The porosity values varied from $0.6 \%$ to $1.0 \%$ (mean of $0.7 \%$ and standard deviation $0.05 \%$ ). In samples where there is a sand grain domain, but with the presence of silt and clay, the porosity reduction was verified. The density parameter is a mirror image of the porosity and thus the parameters described above occurred inversely with the density data. Information on the magnetic and mineralogical composition of the sediments was obtained by means of the magnetic susceptibility curve, since it is calculated for the ability of a material to magnetize itself, when exposed to an induced magnetic field (CHANNEL et al., 2006; Schultheiss et al., 2011). The core showed a change from $-38.47 \times 10^{-5}$ to $-13.54 \times 10^{-5} \mathrm{SI}$ (mean of $-33.80 \times 10^{-5} \mathrm{SI}$ and standard deviation of $6.09 \times 10^{-5} \mathrm{SI}$ ) (Figure 2).

Higher values of magnetic susceptibility close to the top of the core indicate the presence of diamagnetic minerals, such as calcite and quartz, while lower values point to the presence of clay and dolomite minerals. Magnetic susceptibility signal could have been attenuated due to the PVC tube coating of the cores (CHANNEL et al., 2006) (Figure 2).

Gammaspectrometry for the LBE18-1 core showed coherent values of the radiation emitted by the elements 
Uranium (U), Potassium (K) and Thorium (Th). Potassium presented a variation between $2.1 \%$ and $2.9 \%$ (mean of $2.4 \%$ and standard deviation $0.1 \%$ ), where its occurrence is directly associated with variations in the amount of micas, k-feldspars, and weathered clay minerals (Serra et al., 1980). The uranium element presented a variation between $1.4 \mathrm{ppm}$ to $4.8 \mathrm{ppm}$ (average of $3.0 \mathrm{ppm}$ and standard deviation of $0.8 \mathrm{ppm})$, where high concentrations in carbonate rocks are not related only to the clay fraction, but also can be associated to organic sources. For thorium values between $18.4 \mathrm{ppm}$ to 27.9 ppm (mean of $22.5 \mathrm{ppm}$ and standard deviation $1.9 \mathrm{ppm}$ ) were observed. Significant concentrations of thorium are interpreted as radioactive clays and heavy minerals present in sediments such as monazite, torite, zircon, titanite and allanite (Durrance, 1986). In the total count graph, a variation from 99.1 to 121.0 (mean of 108.8 and standard deviation of 5.8) was verified, being an important factor for the calculation of the amount of clay within a carbonate. The $\mathrm{U} / \mathrm{Th}$ ratio shows a relationship between the two radioactive elements during deposition in the Brejo do Espinho Lake, allowing the visualization of the marine and continental influence, since they are related to the predominance of $\mathrm{U}$ and $\mathrm{Th}$ concentrations, respectively (Figure 2 ).

In order to evaluate the mineralogy, XRD analysis was performed for different samples. The values of the most intense peaks were verified and compared with standards according to the literature BRINDLEY \& BROWN, 1980. Minerals such as calcite $\left(\mathrm{CaCO}_{3}\right)$, magnesian calcite $\left((\mathrm{Ca}, \mathrm{Mg}) \mathrm{CO}_{3}\right)$, dolomite $\left(\mathrm{CaMg}\left(\mathrm{CO}_{3}\right)_{2}\right)$, quartz $\left(\mathrm{SiO}_{2}\right)$, weddellite $\left(\mathrm{Ca}\left(\mathrm{CO}_{2}\right)_{2} .2\left(\mathrm{H}_{2} \mathrm{O}\right)\right)$, gypsum $\left(\mathrm{CaSO}_{4} .2 \mathrm{H}_{2} \mathrm{O}\right)$, aragonite $\left(\mathrm{CaCO}_{3}\right)$ and ankerite $\left(\mathrm{Ca}(\mathrm{Fe}, \mathrm{Mg}, \mathrm{Mn})\left(\mathrm{CO}_{3}\right)_{2}\right)$, present significant variation in quantity through the core LBE18-1 (Figure 3).
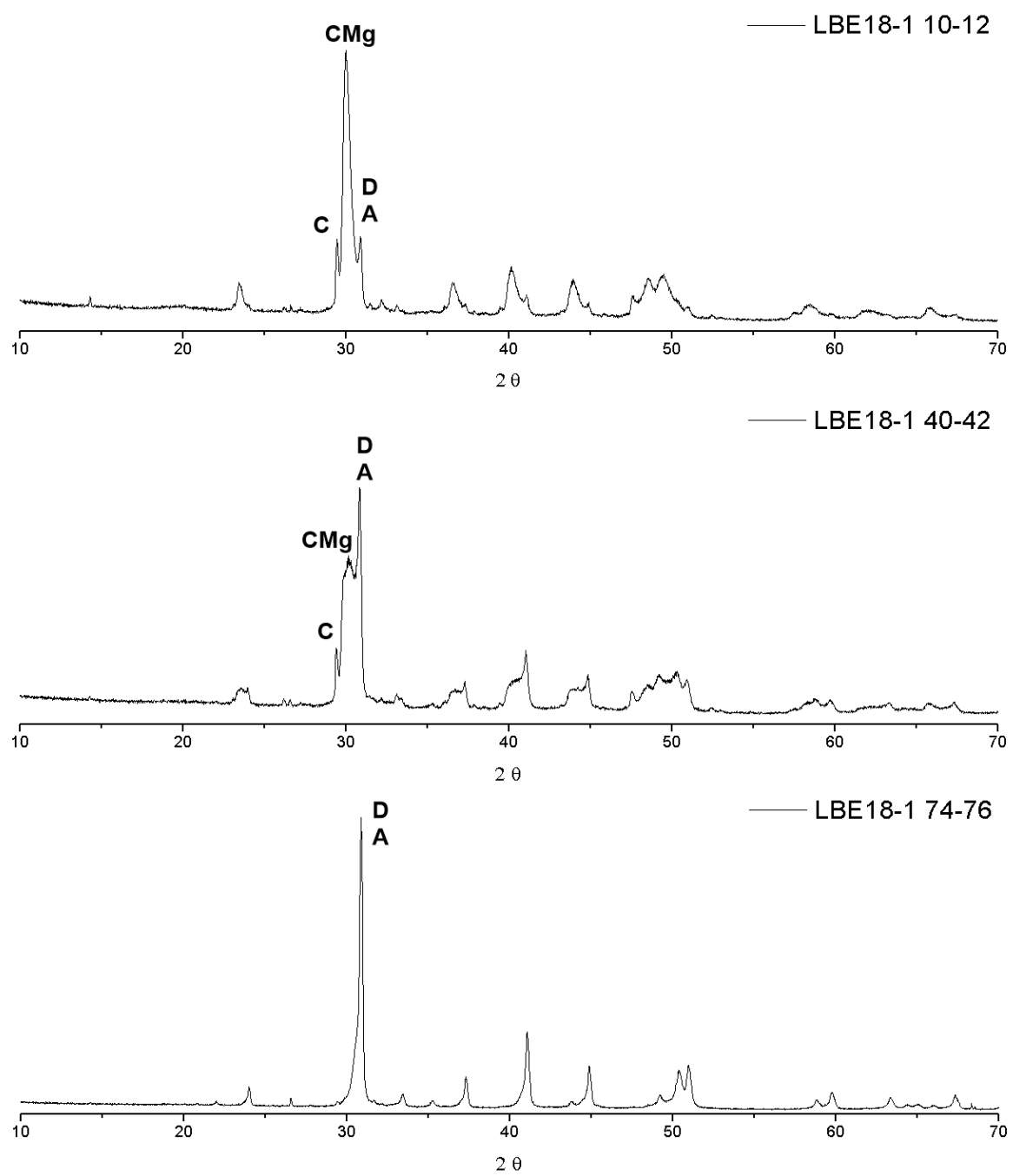

Figure 3 - XRD analysis of representative selected samples from the LBE18-1core. C means calcite, CMg means magnesian calcite, $D$ means dolomite and $A$ is ankerite. 


\section{Conclusion}

The analysis of grain size, seismic profiling, gammaspectrometry and $x$-ray diffraction, allowed the identification and study of the carbonate sediment of the Brejo do Espinho Lake, in which three geological units were observed along the LBE18-1 core (Figure 4):

- At the base, the first unit is represented between depths of $100 \mathrm{~cm}$ to $72.5 \mathrm{~cm}$, with dominant grain size of medium and coarse silt, showing a lighter color and porosity and density curves following grain size variation. The XRD analysis showed a predominance of ankerite, with smaller amounts of dolomite, whereas the magnesian calcite had the lowest values on the core. Thus, these minerals influence the magnetic susceptibility curve, presenting the lowest values found in LBE18-1;

- The second unit is limited between depths $73 \mathrm{~cm}$ to 26 $\mathrm{cm}$, with predominantly fine sand, with important clay percentages. Mineralogy showed a predominance of ankerite and dolomite. The magnetic susceptibility presented similar values with the first unit;

- The third unit, between depths $25 \mathrm{~cm}$ to $0 \mathrm{~cm}$, presented variable grain size between fine sand and coarse silt, resulting in an increase in density and a decrease in porosity. Significant amounts of magnesian calcite and dolomite were observed in these samples, closer to the top of the core. The high magnetic susceptibility, when compared to the rest of the core, can be explained due to the predominance of this magnesian calcite.

The different physical analyzes carried out in the LBE18-1 core showed good contrasting responses, demonstrating that the characterization of a sedimentary succession through chemical stratigraphy, physical and mineralogical properties is effective as a tool in the reconstruction of the paleoenvironmental evolution of Brejo do Espinho Lake.

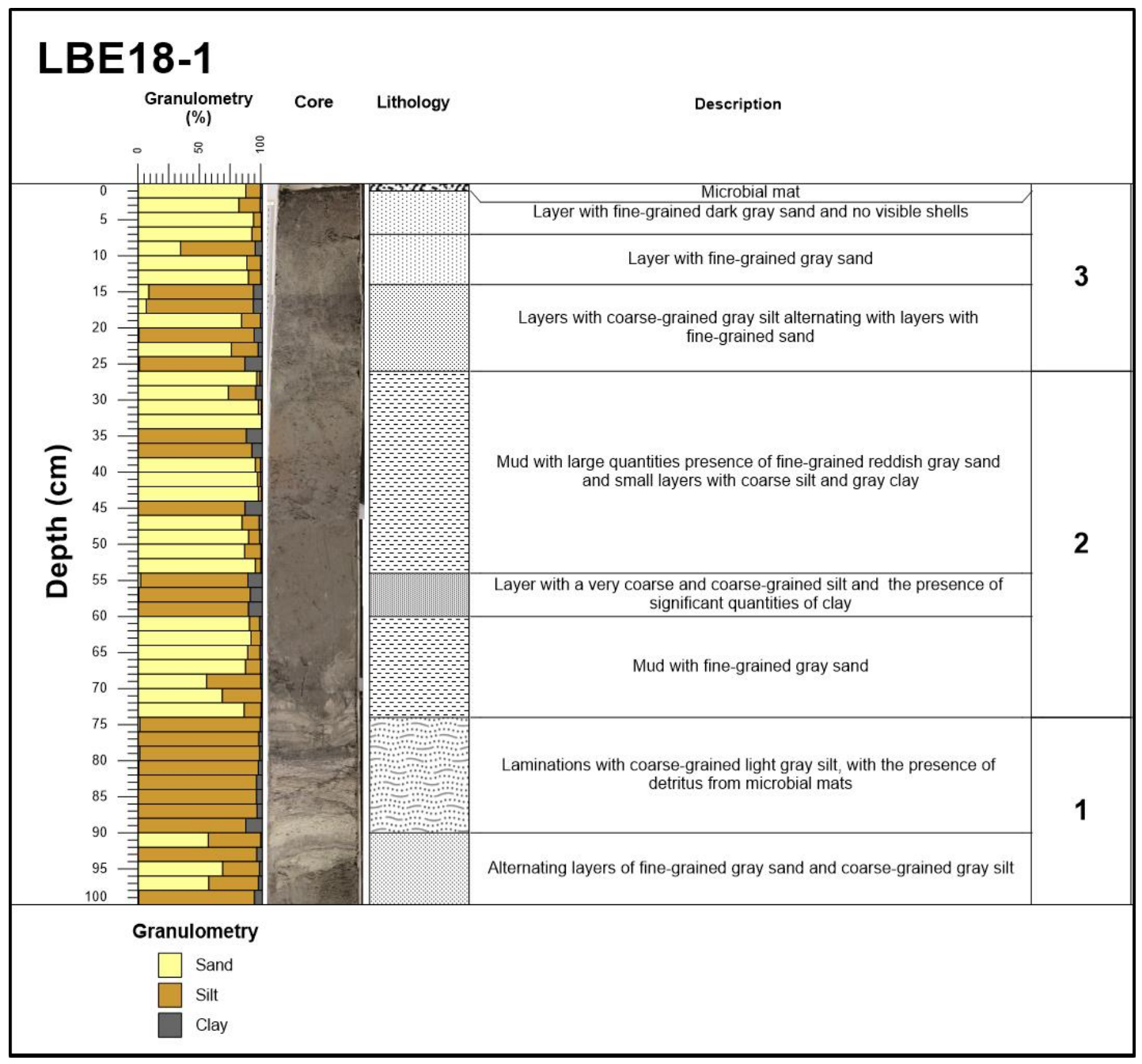

Figure 4 - Summary of the lithology and grain size found in core LBE18-1. 


\section{Acknowledgements}

Thanks to Professor Nicolas M. Strikis (UFF) and Msc. Daniel Souza dos Santos (UFRJ) for help in the coring of LBE18-1. To Professors Antônio Fernando Freire, Arthur Ayres-Neto (UFF), Jeniffer Alves Nobre and Beatriz Lessa de Jesus (Geophysics - UFF) for the acquisition of gamaespectrometry data. Thanks also to the lab technician Leandro Candeia dos Anjos (UFF) who helped with lab work.

\section{References}

Anjos, A.P.A., Siffeddine, A., Patchineelam, S.R. \& Turcq, B., 2003. Dolomita em lagoa hipersalina holocênica no norte fluminense do Rio de Janeiro. 2003. 9. Congresso da Associação Brasileira de Estudos do Quaternário, Recife, 97p

AYRES-NETO, A. Relationships Between Physical Properties and sedimentological Parameters of Near Surface Marine Sediments and their Applicability in the Solution of Engineering and Environmental Problems. 1998. 126 f. Tese (Doutorado) - University of Kiel, Germany, 1998.

BEST, A. I.; GUNN, D. E. Calibration of marine sediments core logger for quantitative

acoustic impedance studies. Marine Geology, v. 160, n. 1-3, p. 137-146, 1999.

Blott, S.J., Pye, K., 2001. GRADISTAT: a grain size distribution and statistics package for the analysis of unconsolidated sediments. Earth Surf. Process. Landforms 26, 1237-1248. http://dx.doi.org/10.1002/esp.261

BRINDLEY, William; BROWN, George. The X-ray identification and crystal structures of clay minerals. London: Mineralogical Society, 1980.

CHANNEL, J. E. T.; KANAMATSU, T.; SATO, T.; STEN, R.; ALVARES ZARIKIAN, C. A.; MALONE, M. J. The expedition 303/306 Scientists. In: Proceedings of the Integrated Ocean Drilling Program. 2006. v. 303/306.

Durrance, E. M. 1986. Radioactivity in geology: principles and applications. Ed. Chichester; E. Hoqwood; New York: J. Willey, $441 \mathrm{p}$.

Folk, R.L., Ward, W.C., 1957. Brazos River bar: a study in the significance of grain size parameters. J. Sediment. Petrol. 27, 326.

HAMILTON, E. L. Variations of density and porosity with depth in deep-sea sediments. Journal of Sedimentary Petrography, $v$. 46 , n. 2, p. $280-300,1976 b$.

HAMILTON, E. L. Sound velocity gradients in marine sediments. Journal Acoustic Society American, v. 65, p. 909-922, 1979.

HOHN, A.; TOBSCHALL, H. J.; MADDOCK, J. E. L. BIOGEOCHEMISTRY OF A HYPERSALINE LAGOON EAST OF RIO DE JANEIRO, BRAZIL. The science of total environment, v. 58, p. $175-185,1986$.
KIM, D. C.; SUNG, J. Y.; PARK, S. C.; LEE, G. H.; CHOI, J. H.; KIM, G. Y.; SEO, Y. K.; KIM, J. C. Physical and acoustic properties of shelf sediments, the South Sea of Korea.Marine Geology, v. 179, p. 39-50, 2001.

LANGFORD, J. I.; DANIEL, L. Powder diffraction. UK: Rep. Prog. Phys., 1996.

MACEDO, H. C. Análise da propagação de ondas compressionais $(P)$ em sedimentos marinhos. Niterói, 2006. 98 f. Dissertação (Mestrado em Geofísica) - Universidade Federal Fluminense, Niterói, 2006.

MARTIN, L. et al. Geologia do Quaternário Costeiro do Litoral Norte do Rio de Janeiro e do Espirito Santo. Belo Horizonte: CPRM/FAPESP, 1997.

SCHULTHEISS, P. J.; ROBERTS, J. A.; CHAMBELAIN, R. GEOTEK Multi-Sensor Core Logger Manual. Disponível em: <http;//www.geotek.co.uk/ftp/manual.pdf>. Acesso em: abr.2011.

Serra, O., Baldwin J., Quirein J. 1980. Theory, interpretation and practical applications of natural gamma ray spectroscopy. Schlumberger Technical Services, Paris, France and Schlumberger Well Services, Houston, Texas, Spwla TwentyFirst Annual Logging Symposium. 1 - 30p.

SPADINI, A. R., DENICOL, P. S., MADRUCCI, V., 2011. Carbonates in Brazil: Challenges in reservoir studies. AAPG Search and Discovery Article \# 90135. AAPG Int. Conf. and Exhibition, Milan, Italy.

TURCQ, B. et al. Origin and evolution of the quaternary coastal plain between Guaratiba and Cabo Frio, State of Rio de Janeiro. In: KNOPPERS, B.; BIDONE, E. D.; ABRÃO, J. J. (Eds.). . Enviromental Geochemistry of Coastal Lagoon Systems, Rio de Janeiro, Brazil. Rio de Janeiri: [s.n.]. p. 25-46.

TURCQ, B.; MARTIN, L.; FLEXOR, J. M.; SUGUIO, K.; PIERRE, C.; TASAYACO-ORTEGA, L. 1999. Origin and evolution of the Quaternary coastal plain between Guaratiba and Cabo Frio, State of Rio de Janeiro, Brazil. In: Knoppers, B.; Bidone E. D.; Abrão J. J. (Ed.) Environmental Geochemistry of coastal lagoon systems, Rio de Janeiro, Brazil. Niterói, RJ: Série Geoquímica Ambiental p. 25-46.

VALENTIN, J. L. Analyse des parametrès hydrobiologiques dans la remontée de Cabo Frio (Brésil). Marine Biology, v. 82, n. 3, p. 259-276, 1984.

VAN LITH, Y. et al. Bacterial sulfate reduction and salinity: Two controls on dolomite precipitation in Lagoa Vermelha and Brejo do Espinho (Brazil). Hydrobiologia, v. 485, p. 35-49, 2002.

VASCONCELOS, C. Sedimentologia e Geoquímica da Lagoa Vermelha - um exemplo de formação e diagênese de carbonatos. [s.I.] Universidade Federal Fluminense, 1988.

Vasconcelos, C.; McKenzie, J. A. 1997. Microbial mediation of modern dolomite precipitation and diagenesis under anoxic conditions (Lagoa Vermelha, Rio de Janeiro, Brazil). Journal of Sedimentary Research, 67: 378-390.

VILLWOCK, J. A. et al. Geologia e geomorfologia de regiões costeiras. In: SOUZA, C. R. DE G. et al. (Eds.). . Quaternário do Brasil. Ribeirão Preto: Holos Editora, 2005. p. 52-74. 